\title{
RUNOFF AND SEDIMENT YIELD FROM LAND UNDER VARIOUS USES IN A MEDITERRANEAN MOUNTAIN AREA. LONG-TERM RESULTS FROM AN EXPERIMENTAL STATION
}

\author{
Estela Nadal-Romero (1), Teodoro Lasanta (2) and José M. García-Ruiz (2)
}

(1) Department of Geography and Land Management, University of Zaragoza, 50009Zaragoza, Spain.

(2) Instituto Pirenaico de Ecología, CSIC, Campus de Aula Dei, P.O. Box 13.034, 50080-Zaragoza, Spain

\begin{abstract}
In this study we analyzed runoff and sediment yield from land under various traditional and current land uses in Mediterranean mountain areas, using long-term data from an experimental station in the Aísa Valley, Central Spanish Pyrenees. The Aísa Valley Experimental Station was established in 1991. The operation and monitoring at this station has provided 20 years of data that can help explain the hydrological and geomorphological changes that have been observed at larger spatial scales, and also the changes that have occurred to some of the most characteristic landscapes of the Mediterranean middle mountains. In spite of the problems associated with the use of small experimental plots (including those related to the lack of connection between the plot and the adjacent hillslope, disturbances introduced by the limits of the plot, and sediment exhaustion), the results obtained are consistent with other studies in the Mediterranean region, and confirm the strong influence of land cover/land use changes on runoff generation and sediment yield. The results indicate that: (i) cereal cultivation on steep slopes (both alternating of cereal cultivation and fallow on sloping fields and shifting agriculture on the steepest slopes) represents a major problem for soil conservation. This explains the occurrence throughout the Mediterranean mountains of many degrades hillslopes, which have thin and stony soils and show evidence of sheet wash erosion, rilling, gullying and shallow landsliding; (ii) farmland abandonment has led to a marked reduction in runoff and sediment yield as a consequence of rapid plant recolonization, particularly where the plant cover is dominated by dense shrubs; (iii) the natural transformation of abandoned fields into grazing meadows has reduced runoff and sediment yield, increasing the availability of grasslands for livestock. Land use
\end{abstract}


trends in the Mediterranean mountains are mainly characterized by generalized farmland abandonment and a decrease in the livestock pressure throughout most of the region. From a hydrological and geomorphological point of view the main consequences have been a reduction in overland flow from the hillslopes, and a reduction in sediment sources, with differences up to one order of magnitude in sediment yield from dense shrub cover and grazing meadow areas compared with areas under shifting agriculture.

Keywords: Experimental plots, runoff, sediment yield, land uses, Mediterranean mountains.

\section{Introduction}

Land use/land cover changes are considered to be one of the most important erosion factors in Mediterranean environments (Poesen and Hooke, 1997; Thornes, 1999; De Vente and Poesen, 2005; García-Ruiz and López-Bermúdez, 2009; Thornes et al., 2009; García-Ruiz, 2010), together with steep slopes and the intensity of rainstorms. It is well known that agricultural and livestock management practices have major impacts on soil characteristics, including infiltration velocity, field capacity and soil water storage. For this reason, changes in land use/land cover cause changes in runoff generation, splash, soil erosion and the location of runoff and sediment sources (GarcíaRuiz et al., 2008; Lana-Renault, 2011), which result in changes in the quality and quantity of water resources. Among the major land use changes with significant hydrological and geomorphological consequences are the expansion of irrigated lands and olive and almond tree orchards in dryland areas, and the abandonment of most cultivated fields in mountain and semiarid areas. Land use/land cover changes were particularly widespread in Mediterranean mountain areas during the 20th century (Lasanta, 1988, 1989; Taillefumier and Piégay, 2003; Bakker et al., 2008). For instance, approximately 75 years ago, steep south-facing slopes of the Spanish Pyrenees were extensively cultivated with cereals followed by fallow on an alternating yearly cycle. On the most marginal slopes, shifting agriculture prevailed, with two or three years of cultivation alternating with 25-30 years of fallow (Lasanta et al., 2006). During the 1950's and 1960's most of the cultivated fields on the hillslopes were abandoned, initiating a complex process of plant recolonization that resulted in a generalized expansion of shrubs and forests (Vicente-Serrano et al., 2000). The fields in the bottom 
of the valley are still cultivated, although cereal crops have been replaced by grazing and cutting meadows. Most recent related studies in the Spanish Pyrenees suggest that these changes have been responsible for the decline in water resources, the spatial contraction of sediment sources, and the decreased sediment load and silting in the reservoirs, both at regional scales (Beguería et al., 2003; García-Ruiz et al., 2011) and in small experimental catchments (García-Ruiz et al., 2008, 2010).

In this study we analyzed the hydrological and geomorphological consequences of land use changes that have occurred recently in the Central Pyrenees, using data from the Aísa Valley Experimental Station (AVES). Long-term studies of traditional and current land uses/land covers have been undertaken in experimental plots at the AVES. The data from 20 years of studies at this experimental station can help explain the hydrological and geomorphological changes that have been observed at larger spatial scales, and the changes that have occurred to many of the most characteristic landscapes of the Mediterranean middle mountain areas, where human activities were most intense. This is a key scientific and applied problem because mountain areas worldwide, and particularly those in the Mediterranean area, are crucial for runoff generation and the supply of water to lowlands and coastal areas for agriculture, industry, cities and tourist resorts (Vivirioli et al., 2003, 2007). As changes in land use/land cover affect the quantity and quality of water resources, indirectly they affect the livelihoods of millions of people.

\section{Study area}

The AVES is located at $1240 \mathrm{~m}$ a.s.l. in the Aísa Valley, Central-Western Spanish Pyrenees (Fig. 1); it is on a south-facing slope with a gradient of about 32\%, in an abandoned field that was cultivated until 50 years ago. The bedrock is composed of Eocene flysch with alternating thin beds of sandstone and marl. The soil is stony and thin, low in nutrients and organic matter (1.5\%), and rich in carbonate (Ruiz-Flaño, 1993).

The climate is subMediterranean with mountain area characteristics. The average annual precipitation at Aísa (1100 m a.s.l.) is $1100 \mathrm{~mm}$, and the average annual temperature is $10^{\circ} \mathrm{C}$. The wettest period annually is from November to May, although a slight decrease in precipitation occurs in January and February. The summer is relatively dry, although some rainstorms can occur, particularly in July. 
The area where AVES is located is representative of those parts of the Pyrenees most affected by centuries of human activity (particularly agriculture on steep slopes and grazing with occasional human-induced fires intended to avoid the expansion of thorny shrubs), and by land use /land cover changes in the last 60-70 years.

When the AVES was established in 1991 the abandoned field had already been colonized by a dense cover of shrubs dominated by Genista scorpius but including Rosa gr. canina and Juniperus communis.

\section{Materials and methods}

The AVES was established with nine closed plots of $10 \times 3 \mathrm{~m}$ to study the hydromorphological behavior of various traditional and current land management practices in Mediterranean mountains (Fig. 2). The land uses in the nine plots were:

(i) Dense shrub cover, corresponding to the undisturbed plant cover several decades following farmland abandonment.

(ii) Grazing meadow, derived from clearing of the shrub cover. Under natural conditions this plot represents the evolution of an abandoned field when it is regularly grazed.

(iii) Cereal cultivation (barley), with chemical fertilizer added. This plot is representative of cultivation on sloping fields. In the traditional system livestock manure was used rather than chemical fertilizer.

(iv) Fallow land. This plot represents the year following cereal cultivation in a traditional rain-fed alternating annual cultivation/fallow agricultural system. In the fallow phase the soil is ploughed one or more times during the year, and remains without plant cover. This plot alternates year after year with the cereal plot.

(v) Land abandoned field after two years of cereal cultivation. Once abandoned the plot was recolonized, initially by herbaceous plants but within ten years by an increasing proportion of shrubs. Plant colonization in this plot was relatively fast as it received chemical fertilization.

(vi) Active shifting agriculture. This plot represents the cultivation of very steep slopes with stony soils, which occurred when demographic pressure led to the cultivation of marginal areas of very low productivity, in the absence of any soil conservation measures. To prepare this plot, we followed traditional farming practices: the shrubs on the plot were cut, piled up, covered with earth and then burnt slowly. The ashes were distributed over the plot as fertilizer. This fertilizing system supplied few 
nutrients to the soil, as the ashes only represent $2.5 \%$ of the plant, and have only low content of N (1.24\%), P (0.05\%), K (0.29\%), Ca (0.53\%) and Mg (0.08\%) (Lasanta et al., 2006).

(vii) Abandoned shifting agriculture. This plot was abandoned in 1996 following four years of cereal cultivation under a shifting agriculture system. Its evolution following farmland abandonment was slower than that of abandoned fields represented by plot (iv), as it received ashes as the only fertilizer during cultivation.

The AVES has two other plots in which the original shrub cover was burnt in 1991 (plot viii) and in both 1993 and 2001 (plot ix). Data from these plots (primarily sediment yield and solute release) was used to study the consequences of humaninduced fires on soil hydrology and erosion (Cerdà and Lasanta, 2005; Lasanta and Cerdà, 2005).

Each plot has a Gerlach canal at the lower end to gather runoff and sediment during each rainstorm event. The canals direct water and sediment to tipping buckets connected to data loggers, and then to plastic collectors (220 l capacity). Following each rainfall event $1 \mathrm{l}$ of the water is removed from each collector to take a sample for estimating the suspended sediment concentration and solute composition. Each year a vegetation survey was performed in each plot to estimate the percentage of herbs and shrubs, and identify the most abundant species. Precipitation is recorded using a pluviometer (0.2 $\mathrm{mm}$ resolution), connected to a data logger.

Data from the loggers are downloaded to a computer every 28 days. The data from each plot, covering a period of 19 hydrological years were analyzed statistically, providing monthly and annual averages and standard deviations for runoff $\left(\mathrm{l} \mathrm{m}^{-2}\right)$ and sediment output $\left(\mathrm{g} \mathrm{m}^{-2}\right)$. Box plots were used to provide a visual representation of the average runoff coefficients, erosion rates and data variability, based on 649 rainfall events, 506 of which produced runoff from at least one of the seven studied plots, and 431 produced sediment from at least one of the studied plots. The relationships between precipitation, runoff and sediment yield were assessed using Pearson linear correlations (SPSS 17.0). The residuals from annual correlation values were related over time to assess temporal trends in runoff and sediment yield.

\section{Results}

Land cover evolution 
Figure 3 shows the evolution of plant cover (grasses and shrubs) in four of the experimental plots: dense shrub cover, grazing meadow, abandoned field and abandoned shifting agriculture. The other three plots (cereal, fallow land and active shifting agriculture) were not included as they were ploughed each year, precluding plant recolonization.

The evolution in the dense shrub cover plot was particularly notable. The plot was initially (1992-1995) covered completely by shrubs (Genista scorpius, Rosa sp., and some stands of Juniperus communis and Crataegus monogyna). Beneath the shrub cover, an herbaceous cover (mainly composed of Brachypodium pinnatum and Carex flacca) developed despite the low level of light. This herbaceous layer covered approximately 20\% of the surface area. After 1996 several changes occurred. Some stands of Genista scorpius died, which progressively reduced its abundance from $90 \%$ in 1996 to 80\% between 1997 and 2000, 70\% between 2001 and 2005, and approximately $60-70 \%$ after 2006. The resulting opening of the shrub cover allowed progressive development of the herbaceous cover from 20\% of the surface in 1992 to 30\% in 1997, 50\% in 2002 and 100\% after 2003. This evolution suggests that the presence of $G$. scorpius was time-limited, with almost no regeneration in the same area, and that after approximately 40 years it was affected by senescence, resulting in development of a community that was increasingly more open and complex, comprising various shrub stands and grasses.

The grazing meadow plot showed an irregular evolution, although grasses dominated (almost 100\%), particularly C. flacca, B. pinnatum and Hieracium gr. pilosella, with minor occurrence of others including Sanguisorba minor, Medicago lupulina, M. sativa, Centaurium erythraea, Galium lucidum, Ranunculus monspeliacus, Blackstonia perfoliata, Centaurea jace, and Trifolium pratense. Shrubs (particularly G. scorpius with some Rosa sp., C. monogyna, Juniperus communis and Thymus vulgaris) were present in low abundance (up to 25\% in 2000 and 2005), although they usually represented less $\tan 20 \%$ and in some cases only approximately 5\%. Shrub cover was controlled by cutting most of the shrubs each year, thus simulating the effect of grazing.

The abandoned field had previously been cultivated with cereals until 1993. Once abandoned, the progression of plant colonization was very rapid, such that the plot had $60 \%$ grass cover in the year of abandonment (the rest remaining bare). The coverage reached 90\% in 1995 and 100\% in 1996. Since 1996 the plot has been totally protected by a dense herbaceous cover, although a slight decrease occurred after 2009. 
The most abundant species were B. pinnatum, C. flacca and M. sativa, with smaller proportions of Dactylis glomerata, Vicia orobus, G. lucidum, S. minor, H. gr. pilosella, and M. lupulina. It is notable that some stands of G. scorpius, Rosa sp., T. vulgaris, C. monogyna and J. communis rapidly colonized the plot, representing approximately $20 \%$ between 1997 and 2002, 50\% in 2005, 60\% in 2008, and 75\% after 2009. Thus, the abandoned field was similar to the dense shrub cover plot, as the proportions of shrubs and grasses were comparable.

The evolution of plant colonization in the abandoned shifting agriculture plot was slower than occurred in the "normal" abandoned field, mainly because of the differences in fertilization when they were cultivated. During the first year of abandonment, the abandoned shifting agriculture plot had approximately 30\% cover of grasses (B. pinnatum, C. flacca, G. lucidum, D. glomerata, V. orobus, B. perfoliata, Convolvulus arvensis, M. lupulina and S. minor), which reached $100 \%$ in 2000 and remained at hat level during the study period. However, shrubs did not readily colonize this plot, and there was only a slow development of Genista scorpius. By 2003, eight years after abandonment, the shrubs only represented 5\% of the soil surface cover. This had increased to only 15\% by 2008 and 40\% by 2011 .

\section{Relationships between precipitation, runoff and sediment yield}

Table 1 shows the regressions performed between precipitation and runoff, precipitation and sediment yield, and runoff and sediment yield. All of the rainfall events considered (649 in total) were coincidental in all of the plots. All the correlations are significant at $\mathrm{p}<0.01$. In several cases, the exponential correlations are included, where they represent a clear improvement of the relationships.

In general, the greatest correlations were found between precipitation and runoff, and thus much of the variability in runoff is explained by the variability in precipitation. Strong correlations were also found between runoff and sediment yield, particularly for the fallow land plot, whereas the lowest $r$ values corresponded to the cereal plot and the active shifting agriculture plot. However, the relationships between precipitation and sediment, although significant, were relatively weak, particularly in the fallow land, cereal and active shifting agriculture plots. These weaker correlations were a result of the small or nonexistent sediment response to many rainfall events.

In several plots there were two responses to precipitation and runoff: (i) a clear increase in sediment yield with an increase in precipitation and runoff; and (ii) a low 
level of sediment yield regardless of the volume of precipitation and runoff. This was particularly evident in the relationship between runoff and sediment yield, and especially in the case of the dense shrub cover, fallow land, abandoned field, abandoned shifting agriculture and active shifting agriculture plots. Additional analyses were performed using exponential correlations, yielding very high correlation coefficients (approximately $r=0.9 ; \mathrm{p}<0.01$ ). Based on the occurrence of two responses of sediment yield to precipitation and runoff, additional linear correlation analyses were performed using those events exceeding a certain sediment yield threshold. This was the case for the grazing meadow $\left(>10 \mathrm{~g} \mathrm{~m}^{-2}\right)$ and the cereal $\left(>50 \mathrm{~g} \mathrm{~m}^{-2}\right)$ plots. No increase in the correlation was found for the grazing meadow plot, but a clear increase in the r value was found for the cereal plot, for the relationships between both precipitation and sediment yield $(r=0.667 ; \mathrm{p}<0.01)$ and runoff and sediment yield $(r=0.875 ; \mathrm{p}<0.01)$.

Linear correlations among precipitation, runoff and sediment yield were also performed at a seasonal scale for each land use/land cover (Table 2). The r values were relatively high for all the seasons for any land use/land cover with respect to the relationships between precipitation and runoff. However, major contrasts were found for the seasonal relationships between runoff and sediment yield, particularly for the fallow land plot ( $r=0.822$ in winter; $r=0.194$ in summer), the cereal plot ( $r=0.821$ in spring; $r=0.359-0.395$ in summer, autumn and winter), and the abandoned shifting agriculture plot ( $r=0.767-0.786$ in spring, summer and winter; $r=0.397$ in autumn).

\section{Runoff generation}

Average annual runoff $\left(\mathrm{l} \mathrm{m}^{-2}\right)$ from each plot is shown in Table 3 and Figure 4. The differences between plots were statistically significant $(p<0.01)$. Three groups of plots were distinguished:

(i) The lowest runoff yield values and standard deviations were found for the dense shrub cover $\left(64.3 \mathrm{l} \mathrm{m}^{-2}\right)$ and grazing meadow $\left(96.2 \mathrm{l} \mathrm{m}^{-2}\right)$ plots.

(ii) A moderate runoff yield was found for the abandoned field plot $\left(132.6 \mathrm{l} \mathrm{m}^{-}\right.$ $\left.{ }^{2}\right)$.

(iii) The plots related to agricultural activities (cereal, fallow land and active shifting agriculture plots) produced the greatest runoff yields. The abandoned shifting agriculture plot was included in this group, due to the greater deviation of the extremes, although its average yield $\left(162.7 \mathrm{l} \mathrm{m}^{-2}\right)$ was almost similar that of the abandoned field plot. 
Runoff from the active shifting agriculture plot was four-fold that from the dense shrub cover plot, and three-fold that from the grazing meadow plot. Given that the average annual precipitation is $1216.7 \mathrm{~mm}$, the runoff coefficients ranged from 5.5 in the dense shrub cover plot to up to 19.4 and 20.5 in the fallow land and the cereal plots, respectively.

The results at a monthly scale for the hydromorphological effects of various land uses confirmed those obtained at an annual scale i.e. for each month of the year moderate runoff yields were found from the dense shrub cover and grazing meadow plots, and high levels of runoff occurred from the active shifting agriculture, cereal and fallow land plots. Nevertheless, some contradictory results were found in the analysis of individual months, where there was disagreement between the data for precipitation and runoff (Fig. 5):

(i) In general, runoff was related to precipitation, such that months with the greatest runoff volumes corresponded to those months with the highest levels of precipitation.

(ii) The monthly evolution of the runoff coefficients was very irregular and, although related to precipitation, was also related to temperature and the water consumption by the plant cover.

(iii) October is the rainiest month of the year, but, in general, the runoff yield in this month was relatively low, particularly in the case of the grazing meadow, abandoned field and active shifting agriculture plots.

(iv) Summer is very dry despite relatively high levels of precipitation in September. In some plots there was almost no runoff recorded in August and September (dense shrub cover, grazing meadow, abandoned field and abandoned shifting agriculture plots). Low runoff values were also recorded in July. The summer runoff coefficients were very low (in general less than 2\% in August), except in the shifting agriculture plot.

(v) The greatest runoff response occurred in April for the cereal, fallow land, abandoned field, and abandoned and active shifting agriculture plots, which coincided with high levels of precipitation following the relatively wet March period. High levels of runoff generation also occurred in April in the grazing meadow plot. In contrast, the runoff yield rapidly decreased in May despite high levels of precipitation.

(vi) January tended to be associated with a high degree of hydrological response, particularly in the cereal and abandoned field plots. 
(vii) In spite of the low level of precipitation in February, the greatest runoff coefficients were found in most plots in this month, reaching $45.2 \%$ in the cereal plot, $50.9 \%$ in the fallow land plot and $66.5 \%$ in the active shifting agriculture plot.

\section{Suspended sediment yield}

Table 3 and Figure 6 show the suspended sediment yield from the various land uses, and indicate that large differences occurred among plots. The results show a similar pattern to that of runoff. Three groups of plots were distinguishable with respect to sediment yield:

(i) The dense shrub cover plot produced the smallest average annual suspended sediment yield (41.5 $\mathrm{g} \mathrm{m}^{-2}$ ), followed by the grazing meadow plot $\left(69.7 \mathrm{~g} \mathrm{~m}^{-2}\right)$.

(ii) Intermediate yields were found for the abandoned field $\left(165.1 \mathrm{~g} \mathrm{~m}^{2}\right)$ and the abandoned shifting agriculture (199.1 $\left.\mathrm{g} \mathrm{m}^{-2}\right)$ plots. The fallow land plot $\left(216 \mathrm{~g} \mathrm{~m}^{-2}\right)$, which appeared to have more moderately erosive and hydrological behavior, was included in this group.

(iii) The greatest yields of suspended sediment were found for the active shifting agriculture (437.3 $\mathrm{g} \mathrm{m}^{-2}$ ) and cereal $\left(378.5 \mathrm{~g} \mathrm{~m}^{-2}\right)$ plots.

The average value of suspended sediment yield from the active shifting agriculture plot was more than ten-fold greater than that from the dense shrub cover plot, and seven-fold greater than that from the grazing meadow plot. It is also noteworthy that the suspended sediment yield from the active shifting agriculture plot was twice that from the abandoned shifting agriculture plot, emphasizing the hydrological differences between these plots. In addition, the sediment yield from the cereal and fallow land plots was four-fold that from the abandoned field plot.

The monthly sediment yield differed substantially among months and land uses (Fig. 5).

(i) Tipically there was almost no sediment yield in August and September, except from the cereal, fallow land and active shifting agriculture plots. The abandoned field and abandoned shifting agriculture plots were similar in yield to the dense shrub cover and grazing meadow plots, highlighting that a dense plant cover is sufficient to protect the soil from summer rainstorms.

(ii) The maximum sediment yield was recorded in the grazing meadow, cereal and active shifting agriculture plots in April-May, in January for the dense shrub cover plot, and in December-January for the fallow land, abandoned field and abandoned 
shifting agriculture plots. Figure 5 shows the occurrence during the year of two welldefined sediment peaks (one in winter and the other in spring) and troughs (one in summer and the other at the end of winter, mainly in March).

(iii) Almost no suspended sediment was recorded in October for any of the land uses, in spite of the high precipitation levels; the exceptions were in the cereal and active shifting agriculture plots, due to ploughing works in the field before seeding.

(iv) The largest monthly contrasts occurred in the most active agricultural plots (cereal, fallow land, and active shifting agriculture plots).

(v) The most active month with respect to sediment yield was April), when the yield from the active shifting agriculture plot $\left(59.5 \mathrm{~g} \mathrm{~m}^{-2}\right)$ was fifteen-fold greater than that from the dense shrub cover plot $\left(3.8 \mathrm{~g} \mathrm{~m}^{-2}\right)$, and ten-fold than that from the grazing meadow plot $\left(5.4 \mathrm{~g} \mathrm{~m}^{-2}\right)$.

\section{Trends in runoff and sediment yield}

Figures 7 and 8 show the temporal trends observed in the relationships among precipitation, runoff and sediment yield for each land use, based on the residuals from the respective bilateral annual correlations. No trends in runoff were found (Fig. 7), except for the fallow land plot $(r=0.665)$, which indicates a progressive increase in runoff generation. The abandoned and active shifting agriculture plots also showed slight positive trends, although they were not statistically significant. Not any trend was recorded in the other plots.

The results were more consistent in the case of sediment (Fig. 8), for which negative trends were generally found. The highest correlation coefficients were obtained for the two abandoned plots (abandoned field and abandoned shifting agriculture plots), which were both affected by the greatest land cover changes and a progressive increase in plant cover. Nevertheless, it is noteworthy that the residuals have remained almost constant since 2001, particularly in the abandoned field, indicating that sediment yield has not been affected by any other changes in plant cover. The cereal, fallow land and active shifting agriculture plots also underwent a decrease in sediment yield, suggesting sediment exhaustion related to the specific conditions of closed plots. This was particularly evident in the case of the fallow land plot, in which the decrease in sediment yield coincided with an increase in runoff generation.

\section{Discussion and conclusions}


Long-term experimental stations such as the AVES (20 years) provide data enabling comparisons of runoff and sediment yield from different land uses, which facilitate interpretation of landscape evolution and sustainable management of the Mediterranean mountains. The results also enable assessment of the hydromorphological effects of traditional and current land uses.

The results from closed experimental plots need to be interpreted with caution, and only used for comparative purposes within the same experimental station (BoixFayos et al. (2006, 2007). For example, there is a hydrological disconnect between closed plots and the adjacent environment. In studies of hillslopes the effects include a reduced length of overland flow and impeded sediment renewal from the upper part of the slope. In the case of small plots, rainsplash is better represented than sheet wash erosion or rilling. In addition, the presence of borders around the plots produces many effects, particularly during the years immediately following establishment. In our study the negative trend in sediment yield observed in some plots suggests that sediment exhaustion occurred several years after initiation of the experiment. Not surprisingly, the plots involved were not those directly affected by plant recolonization, as the negative sediment trend was not related to precipitation or plant cover changes (cereal, fallow land and active shifting agriculture plots). Boix-Fayos et al. (2006) argued that it is impossible to extrapolate erosion and sediment transport results from experimental plots to catchments, because of the different ways in which water and sediment connectivity occurs.

Nevertheless, despite the many limitations of experimental plots, the results reported here are consistent with other studies in the Mediterranean region (i.e. Martínez-Fernández et al., 1995; Kosmas et al., 2000; Dunjó et al., 2003), and confirm the strong influence of land cover/land use changes on runoff generation and sediment yield (García-Ruiz et al., 1995). The major findings are as follows.

(i) The dense shrub cover had very moderate hydrological and geomorphological effects, with little water and sediment yield. This indicates that a dense shrub cover on hillslopes encourages infiltration and protects the soil. Nevertheless, the decline of $G$. scorpius in the dense shrub cover plot, detected in recent years, could lead to an increase in runoff and sediment yield over the long-term.

(ii) Grazing meadows also had a low water and sediment yield, suggesting that replacement of the dense shrub cover with grazing meadows will no result in particular environmental problems if it occurred in certain places (concavities and lower parts of 
hillslopes). This could increase the availability of grasslands for livestock in Mediterranean mountains, where the expansion of thorny shrubs has become a problem in recent decades (Lasanta et al., 2009).

(iii) Cereal cultivation of steep slopes represents a major problem for soil conservation; this includes both alternating cereal cultivation and fallow on sloping fields, and the use of shifting agriculture on the steepest slopes. This approach to food production was clearly a solution to the needs of people during the periods of greatest demographic pressure, i.e. the 18th and 19th centuries and the first third of the 20th century. During this period farmers cropped every south-facing slope below $1600 \mathrm{~m}$ a.s.l. (Lasanta, 1989). In the case of shifting agriculture, no soil conservation measures were used (Lasanta et al., 2006). These factors explain the many degraded hillslopes throughout the Mediterranean mountains, which are characterized by thin and stony soils and the occurrence of sheet wash erosion, rilling, gullying and shallow landsliding (García-Ruiz and Valero-Garcés, 1998; Lorente et al., 2002; Regüés et al., 2009). For the Central Pyrenees, Martínez-Castroviejo and García-Ruiz (1990) and Beguería et al. (2006) attributed the development of torrential rivers with wide braided channels overloaded with coarse sediment to the high level of demographic pressure and land degradation that occurred in this period.

(iv) Farmland abandonment resulted in a marked reduction in water and sediment yield because of rapid plant recolonization. In fact, abandoned plots where those with the most consistent negative sediment trend. In the case of the abandoned shifting agriculture plot such a negative trend was slower than in the abandoned field plot. The conditions in each plot at the time of cultivation would have determined the characteristics of soil fertility and plant colonization (Lasanta, 1989; Ruiz-Flaño, 1993). The generalized negative trend in water and sediment yield following farmland abandonment has been confirmed in various European environments, and particularly in the Mediterranean region (Ruiz-Flaño et al., 1992; Beguería et al., 2003; García-Ruiz and Lana-Renault, 2011; García-Ruiz et al., 2011). This has led to decreasing water resources at various spatial scales (García-Ruiz et al., 2010), changes in fluvial channel morphology (Liébault and Piégay, 2001, 2002; Keestra et al., 2005) and alluvial fan activity (Gómez-Villar and García-Ruiz, 2000); difficulties for reservoir management (López-Moreno et al., 2004) and a reduction in sediment transport and siltation of reservoirs (Valero-Garcés et al., 1998; López-Moreno et al., 2003; Beguería et al., 2006; Navas et al., 2009). 
The dominant land use trend in Mediterranean mountains since the middle of the 20th century has been a reduction in land management, with farmland abandonment having occurred in all hillslope areas, and a decrease in livestock number throughout most of the region. This has led to a generalized occurrence of abandoned fields, the substitution of cereal fields by cutting meadows, the expansion of grazing meadows, and colonization of the subMediterranean belt by shrubs and forests. From a hydrological and geomorphological point of view the main consequences have been a reduction of overland flow and discharge on the hillslopes and rivers, respectively, and a reduction in sediment sources. These consequences were indicated by comparison of the sediment yield from the shifting agriculture and cereal plots with those from the abandoned, grazing meadow and dense shrub cover plots, where the yields were up to one order of magnitude different. Similar results have been reported at spatial scales ranging from plots to experimental catchments and entire regions (García-Ruiz et al., 2010), resulting in a new environmental scenario with major consequences for water and land management. The occurrence of trends of decreasing sediment yield from abandoned plots suggests the importance of plant recolonization in reducing erosion (Lasanta et al., 2010), and particularly the consequences of an increasing presence of shrubs, although the effect of sediment exhaustion in closed plots cannot be discounted. We have no explanation for the increase in runoff generation in three of the plots, perhaps related to changes in the infiltration capacity of soils or to the management of the plots. An interesting topic for the future is the evolution of dense shrub cover, the more and more affected by senescence of Genista scorpius and colonization by herbaceous species.

The results indicate strong relationships at the event scale between precipitation and runoff, and between runoff and sediment yield. Two responses to precipitation were evident, the first an increase in runoff and sediment yield with an increase in precipitation, and the second no increase in runoff or sediment yield despite intense rainstorms. A similar duality in the response has also been detected at the scale of experimental catchments, and has been attributed to the antecedent soil conditions (Seeger et al., 2004; Lana-Renault et al., 2007). A weak hydrological response can occur in any season, depending on the height of the water table and the soil humidity, even though the smallest runoff coefficients are found in summer and autumn. For instance, Gallart et al. (2002) reported that intense summer rainstorms usually do not produce any hydrological response in bench-terraced hillslopes of the Upper Llobregat 
basin, Eastern Pyrenees. The occurrence of two sediment peaks at the monthly scale is noteworthy, one in April-May and the other in December (and in some cases January). The April-May peak coincides with a period of rainfall activity and the main runoff peak in spring. However, the peak in December-January occurs during a period of relatively low precipitation, following the main rainfall period in autumn. In this case, it is probable that the sediment peak is related to soil saturation and the consequences of freeze-thaw processes within the soil, although no direct experimental data for this is available from the plots. However, we do know that a frequent freeze-thaw events in marl outcrops enhances the sediment yield from badland areas of the Central Pyrenees (Nadal-Romero and Regüés, 2011), although this situation is not directly comparable to that in the AVES plots.

\section{Acknowledgements}

Support for this research was provided by the projects PROBASE (CGL200611619/HID), MARTINA (CGL2008-05112-C02-01/CLI) and INDICA (CGL201127753-C02-01 and -02), funded by the Spanish Ministry of Economy and Competitivity, and ACQWA (FP7-ENV-2007-1-212250), financed by the European Commission. Monitoring of the Aísa Valley Experimental Station was supported by an agreement between the CSIC and the Spanish Ministry of Environment (RESEL). E. Nadal-Romero was the recipient of a research contract (Spanish Ministry of Economy and Competitivity, Programme Juan de la Cierva).

\section{References}

Bakker MM, Govers G, Van Doorn A, Quetier F, Chouvardas D, Rounsevell M. 2008.

The response of soil erosion and sediment export to land-use change in four areas of Europe: The importance of landscape pattern. Geomorphology 98: 213-226.

Beguería S, López-Moreno JI, Lorente A, Seeger M, García-Ruiz JM. 2003. Assessing the effects of climate oscillations and land-use changes on streamflow in the Central Spanish Pyrenees. Ambio 32 (4): 283-286.

Beguería S, López-Moreno JI. Gómez-Villar A, Rubio V, Lana-Renault N, García-Ruiz JM. 2006. Fluvial adjustments to soil erosion and plant cover changes in the Central Spanish Pyrenees. Geografiska Annaler 88A (3): 177-186. 
Boix-Fayos C, Martínez-Mena M. Arnau-Rosalén E, Calvo-Cases A, Castillo V, Albaladejo J. 2006. Measuring soil erosion by field plots: understanding the sources of variation. Earth-Science Reviews 78: 267-285.

Boix-Fayos C, Martínez-Mena M, Calvo-Cases A, Arnau-Rosalén E, Albaladejo J, Castillo V. 2007. Causes and underlying processes of measurement variability in field erosion plots in Mediterranean conditions. Earth Surface Processes and Landforms 32: 85-101.

Cerdà A, Lasanta T. 2005. Long-term erosional responses after fire in the Central Spanish Pyrenees. 1. Water and sediment yield. Catena 60: 59-80.

De Vente J, Poesen J. 2005. Predicting soil erosion and sediment yield at the basin scale: Scale issues and semi-quantitative models. Earth-Science Reviews 71: 95-125.

Dunjó G, Pardini G, Gispert M. 2003. Land use changes effects on abandoned terraced soils in a Mediterranean cvatchment, NE Spain. Catena 52, 23-37.

Gallart F, Llorens P, Latron J, Regüés D. 2002. Hydrological processes and their seasonal controls in a small Mediterranean mountain catchment in the Pyrenees. Hydrology and Earth System Sciences 6 (3): 527-537.

García-Ruiz JM. 2010. The effects of land uses on soil erosion in Spain. A review. Catena 81: 1-11.

García-Ruiz JM, Valero-Garcés B. 1998. Historical geomorphic processes and human activities in the Central Spanish Pyrenees. Mountain Research and Development 18 (4): 309-320.

García-Ruiz JM, López-Bermúdez F. 2009. La erosión del suelo en España. Sociedad Española de Geomorfología, Zaragoza, 441 pp.

García-Ruiz JM. Lana-Renault N. 2011. Hydrological and erosive consequences of farmland abandonment in Europe, with special reference to the Mediterranean region - A review. Agriculture, Ecosystems and Environment 140: 317-338.

García-Ruiz JM, Lasanta T, Ortigosa L, Ruiz-Flaño P, Martí C, González C. 1995. Sediment yield under different land-uses in the Spanish Pyrenees. Mountain Research and Development 15 (3): 229-240.

García-Ruiz JM, López-Moreno JI, Vicente-Serrano SM, Lasanta T, Beguería S. 2011. Mediterranean water resources in a Global Change scenario. Earth-Science Reviews 105 (3-4): 121-139.

García-Ruiz JM, Regüés D, Alvera B, Lana-Renault N, Serrano-Muela P, NadalRomero E, Navas A, Latron J, Martí-Bono C, Arnáez J. 2008. Flood generation and 
sediment transport in experimental catchments along a plant cover gradient in ther Central Pyrenees. Journal of Hydrology 356: 245-260.

García-Ruiz JM, Lana-Renault N, Beguería S, Lasanta T, Regüés D, Nadal-Romero E, Serrano-Muela P, López-Moreno JI, Alvera, B, Martí-Bono C, Alatorre LC 2010. From plot to regional scales: interactions of slope and catchment hydrological and geomorphic processes in the Spanish Pyrenees. Geomorphology 129: 248-257.

Gómez-Villar A, García-Ruiz JM. 2000. Surface sediment characteristics and present dynamics in alluvial fans of the Central Spanish Pyrenees. Geomorphology 34, 127144.

Keestra SD, Van Huissteden J, Vandenberghe J, Van Dam O. De Gier J, Pleizier ID 2005. Evolution of the morphology of the river Dragonja (SW Slovenia) due to landuse changes. Geomorphology 69: 191-207.

Kosmas C. Gerontidis S, Marathianoy M. 2000. The effect of land use change on soils and vegetation over various lithological formations on Lesvos (Greece). Catena 40, 51-68.

Lana-Renault N. 2011. El efecto de los cambios de cubierta vegetal en la respuesta hidrológica y sedimentológica de areas de montaña: la Cuenca experimental de Arnás, Pirineo Central. Consejo de Protección de la Naturaleza de Aragón, Zaragoza, $189 \mathrm{pp}$.

Lana-Renault N, Regüés D, Martí-Bono C. Beguería S, Latron J, Nadal E, Serrano P, García-Ruiz JM 2007. Temporal variability in the relationships between precipitation, discharge and suspended sediment concentration in a Mediterranean mountain catchment. Nordic Hydrology 38 (2): 139-150.

Lasanta T. 1988. The process of desertion of cultivated areas in the Central Spanish Pyrenees. Pirineos 132: 15-35.

Lasanta T. 1989. Evolución reciente de la agricultura de montaña: El Pirineo aragonés. Geoforma Ediciones, Logroño, 220 pp.

Lasanta T, Cerdà A. 2005. Long-term erosional responses after fire in the Central Spanish Pyrenees. 2. Solute release. Catena 60: 81-100.

Lasanta T, Beguería S, García-Ruiz JM 2006. Geomorphic and hydrological effects of traditional shifting agriculture in a Mediterranean mountain, Central Spanish Pyrenees. Mountain Research and Development 26 (2): 146-152. 
Lasanta T, Arnáez J, Errea MP, Ortigosa L, Ruiz-Flaño P. 2009. Mountain pastures, environmental degradation and landscape remediation: the example of a Mediterranean policy initiative. Applied Geography 29: 308-319.

Lasanta T, Nadal-Romero E, Serrano-Muela P, Vicente-Serrano S, García-Ruiz JM 2010. Escorrentía y erosión tras el abandono de tierras de cultivo en montaña: resultados de la Estación Experimental “Valle de Aísa”. Pirineos 165: 115-133.

Liébault F. Piégay H. 2001. Assessment of channel changes due to long-term bedload supply decrease, Roubion River, France. Geomorphology 36: 167-186.

Liébault F, Piégay F. 2002. Causes of the $20^{\text {th }}$ century channel narrowing in mountain and piedmont rivers of southeastern France. Earth Surface Processes and Landforms 27: 425-444.

López-Moreno JI, Beguería S, García-Ruiz JM. 2004. The management of a large Mediterranean reservoir: storage regimes of the Yesa reservoir, Upper Aragón River basin, Central Spanish Pyrenees. Environmental Management 34 (4): 508-515.

López-Moreno JI, Beguería S, Valero-Garcés B, García-Ruiz JM. 2003. Intensidad de las avenidas y aterramiento de embalses en el Pirineo central español. Ería 61 159168.

Lorente A, García-Ruiz JM, Beguería S, Arnáez J. 2002. Factors explaining the spatial distribution of hillslope debris flows. A case study in the Flysch Sector of the Central Spanish Pyrenees. Mountain Research and Development 22 (1): 32-39.

Martínez-Castroviejo R, García-Ruiz, JM. 1990. Coladas de piedras y dinámica fluvial en ríos torrenciales del Pirineo Central: el caso del río Ijuez. Cuadernos de Investigación Geográfica 16: 55-72.

Martínez-Fernández J, López-Bermúdez F, Martínez-Fdernández J, Romero-Díaz A. 1995. Land use and soil-vegetation relationships in a Mediterranean ecosystem. Catena 25, 153-167.

Nadal-Romero E, Regüés D. 2011. Geomorphological dynamics of subhumid mountain badland areas - weathering, hydrological and suspended sediment transport processes: A case study in the Araguás catchment (Central Pyrenees) and implications for altered hydroclimatic regimes. Progress in Physical Geography 34 (2): $123-150$

Navas A. Valero-Garcés B, Gaspar L, Machín J. 2009: Reconstructing the history of sediment accumulation in the Yesa reservoir: an approach for management of mountain reservoirs. Lake and Reservoir Management 25: 15-27. 
Poesen J, Hooke JM 1997. Erosion, flooding and channel management in Mediterranean environments of southern Europe. Progress in Physical Geography 21 (2): 157-199.

Regüés D, Nadal-Romero E, Latron J, Martí-Bono C. 2009. Producción y transporte de sedimento en cárcavas desarrolladas en la Depresión Interior Altoaragonesa (Cuenca de Araguás, Pirineo Central). Cuadernos de Investigación Geográfica 35 (2), 263287.

Ruiz-Flaño P. 1993. Procesos de erosión en campos abandonados del Pirineo. Geoforma Ediciones, Logroño, 191 pp.

Ruiz-Flaño P, García-Ruiz JM, Ortigosa L. 1992. Geomorphological evolution of abandoned fields. A case study in the Central Pyrenees. Catena 19: 301-308.

Seeger M, Errea MP, Beguería S, Arnáez J, Martí-Bono C, García-Ruiz J.M. 2004. Catchment soil moisture and rainfall characteristics as determinant factor for sicharge/suspended sediment hysteretic loops in a small headwater catchment in the Spanish Pyrenees. Journal of Hydrology 288, 299-311.

Taillefumier F, Piégay H. 2003. Contemporary land use changes in prealpine Mediterranean mountains. A multivariate GIS-based approach applied to two municipalities in the southern French Prealps. Catena 51: 267-296.

Thornes JB. 1999. The hydrological cycle and the role of water in Mediterranean environments. In Rural planning from an environmental systems perspective, F.B. Golley and J. Bellot, (eds.), Springer, Rotterdam, pp. 85-107.

Thornes J, López-Bermúdez F, Woodward J. 2009. Hydrology, river regimes, and sediment yield. In The Physical Geography of the Mediterranean J.C. Woodward (ed.), Oxford University Press, Oxford, pp. 229-253.

Valero-Garcés BL, Navas A, Machín J, Walling D. 1998. Sediment sources and siltation in mountain reservoirs: a case study from the Central Spanish Pyrenees. Geomorphology 28: 23-41.

Vicente-Serrano S. Lasanta T, Cuadrat JM. 2000. Transformaciones en el paisaje pirenaico como consecuencia del abandono de las actividades económicas tradicionales. Pirineos, 155: 111-133.

Vivirioli D, Weingartner R, Messerli B. 2003. Assessing the hydrological significance of the World's mountains. Mountain Research and Development 23: 32-40. 
Vivirioli D, Dürr HH, Messerli B, Meybeck M, Weingartner R. 2007. Mountains of the world - water towers for humanity: typology, mapping and global significance. Water Resources Research 43 (7): W07447.

\section{FIGURE CAPTIONS}

Figure 1. Location of the Aísa Valley Experimental Station.

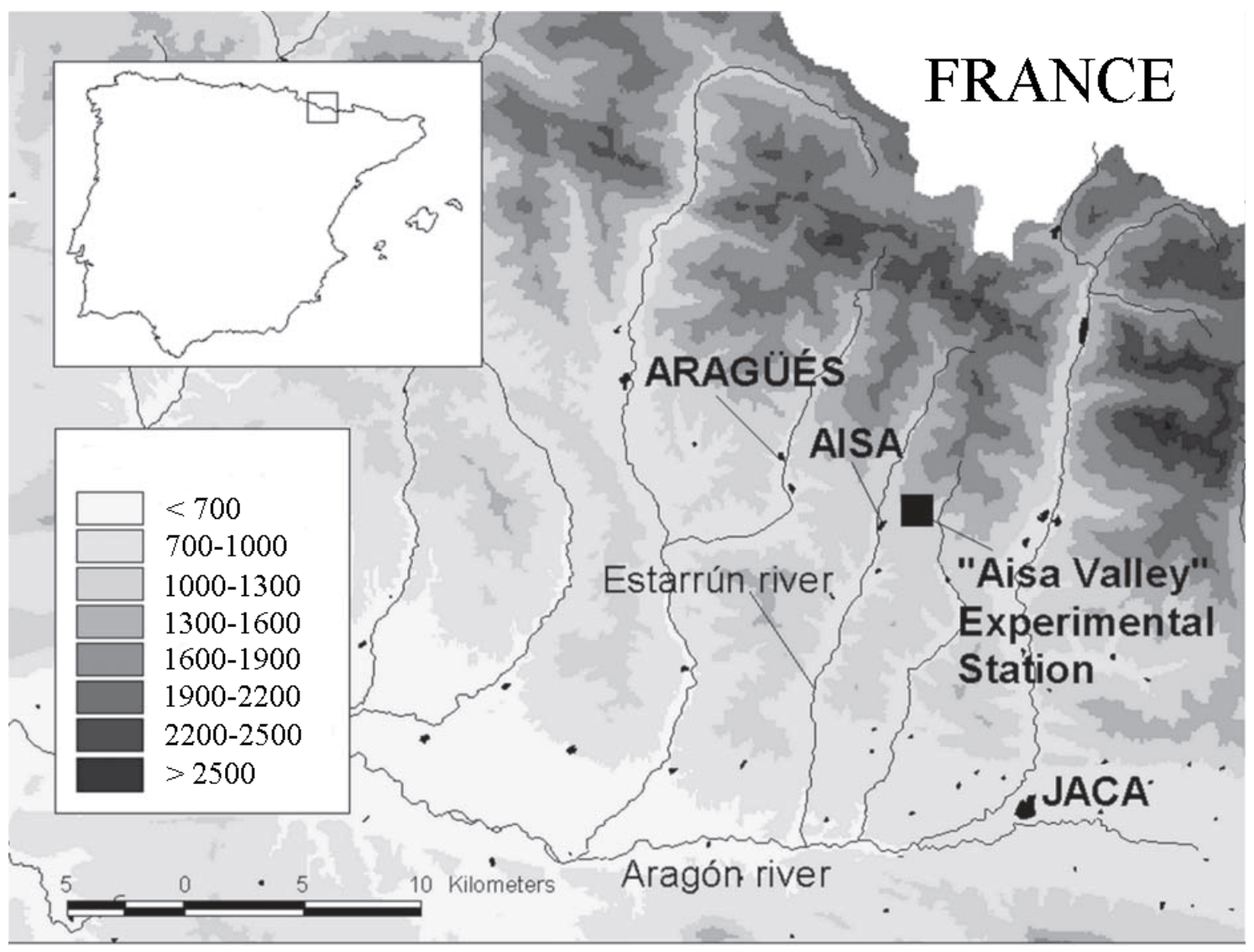


Figure 2. Plots and equipments at the Aísa Valley Experimental Station.

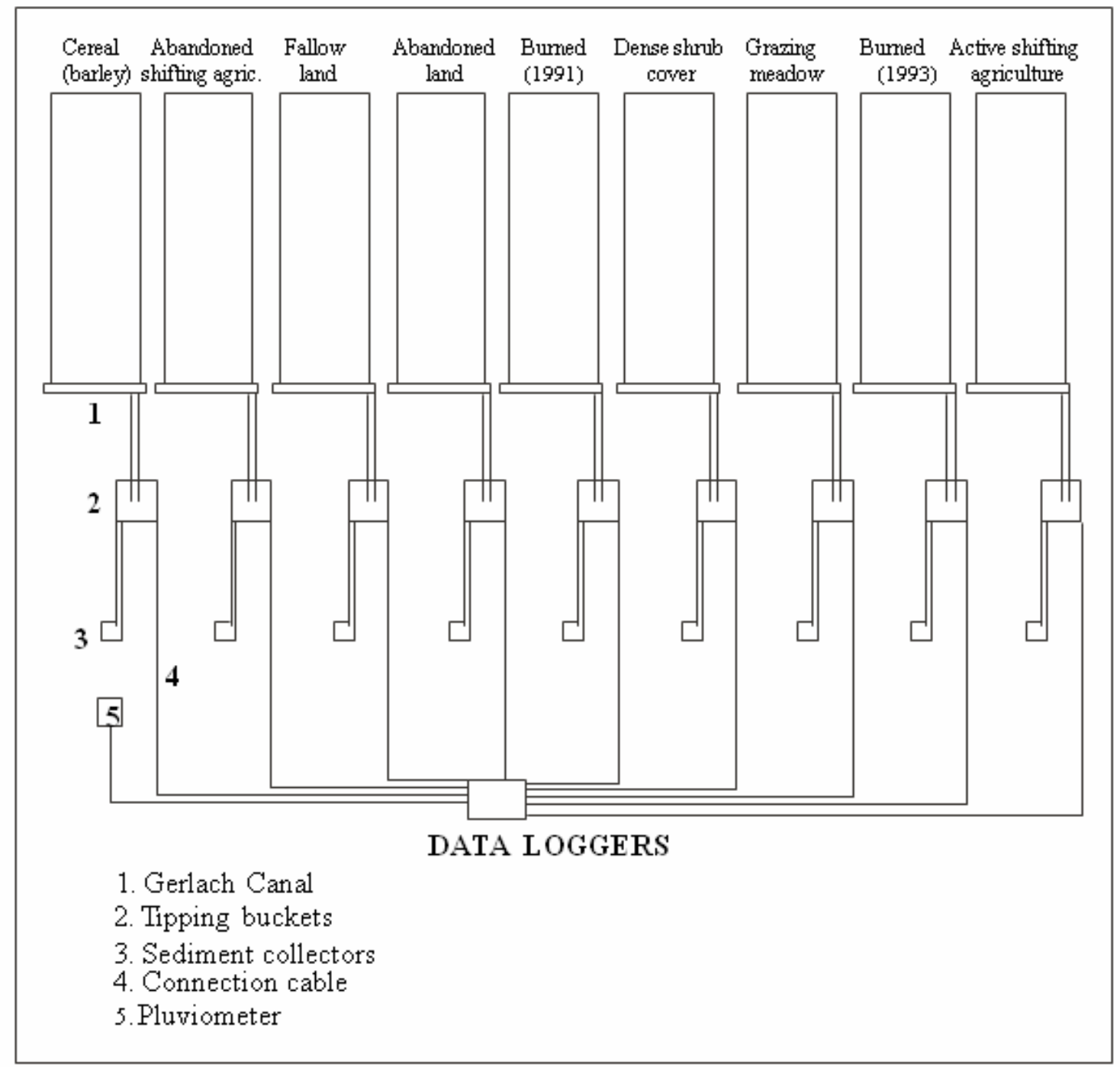


Figure 3. Evolution of plant cover (shrubs and grasses) in four of the experimental plots.
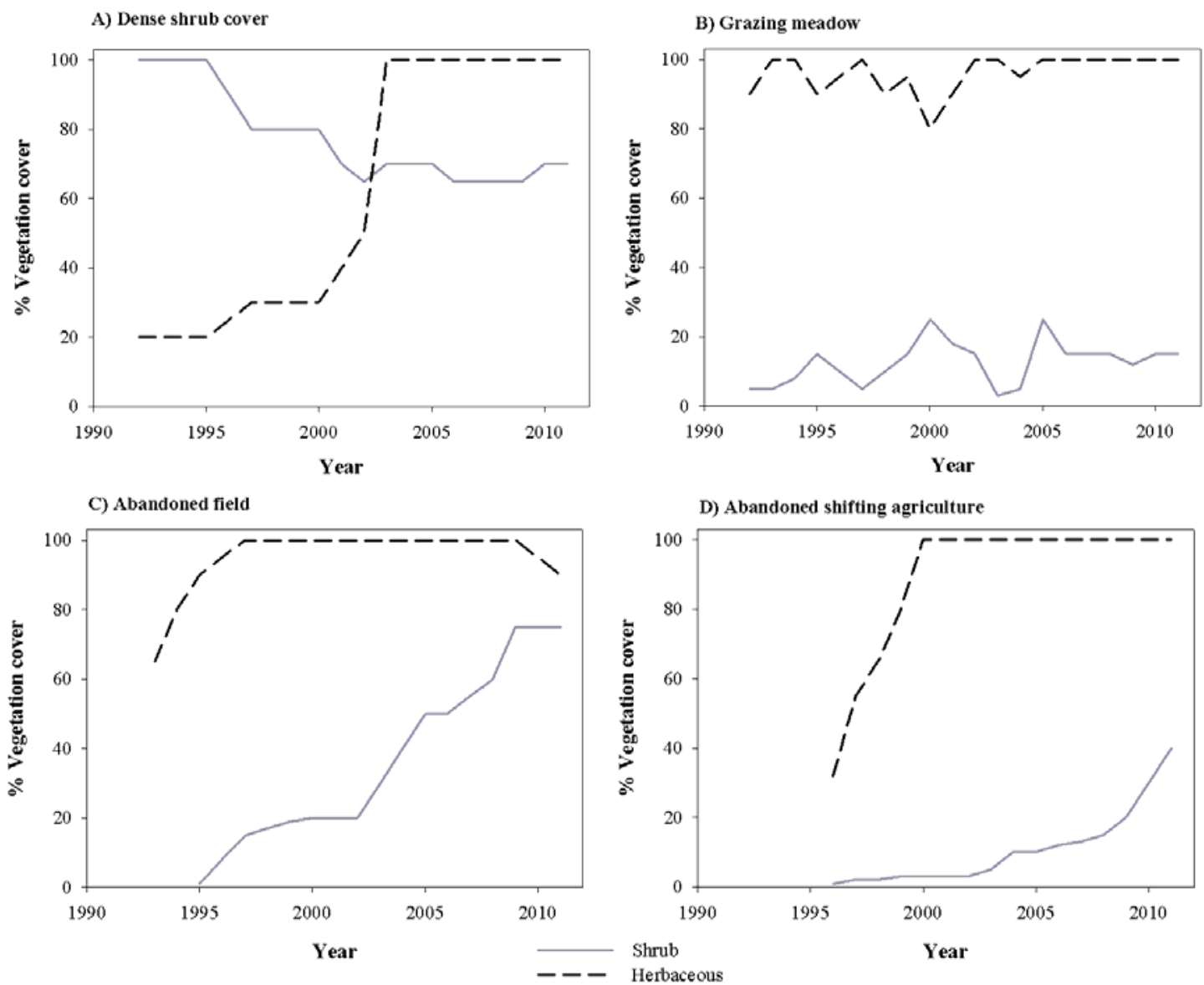
Figure 4. Runoff yield from various land use plots.

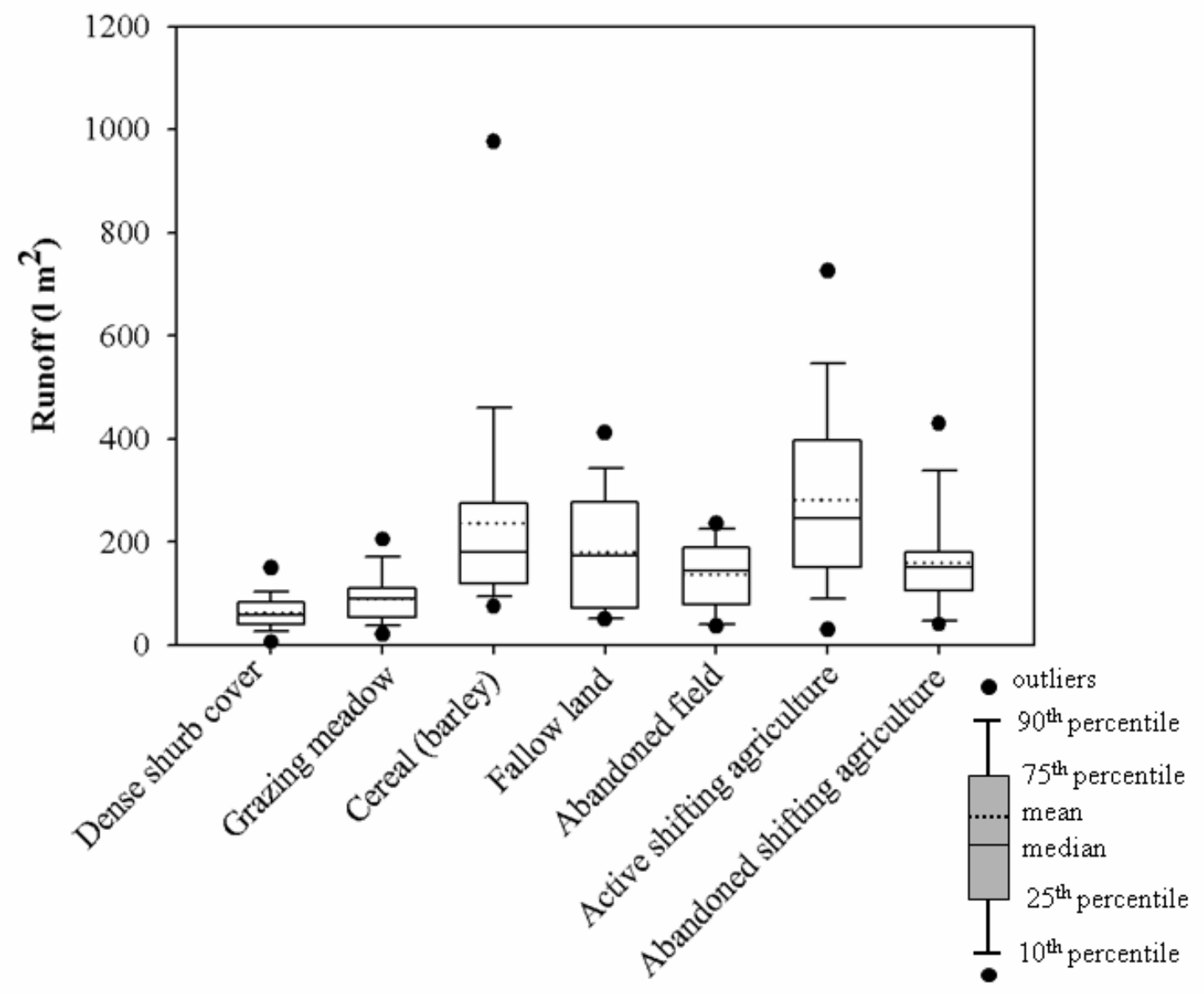

Figure 5. Monthly precipitation, runoff and suspended sediment yield from the various land use plots.

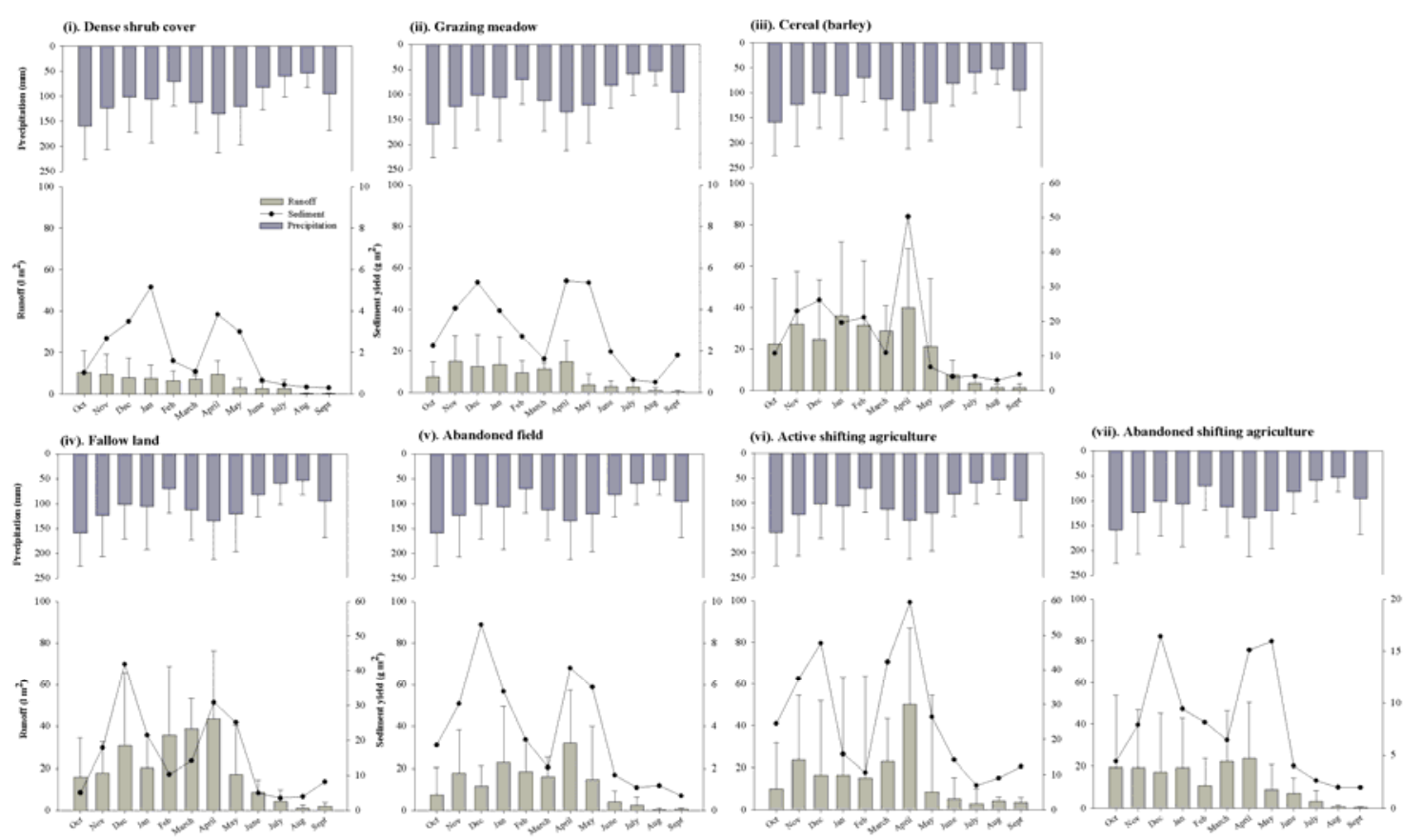


Figure 6. Suspended sediment yield from the various land use plots.

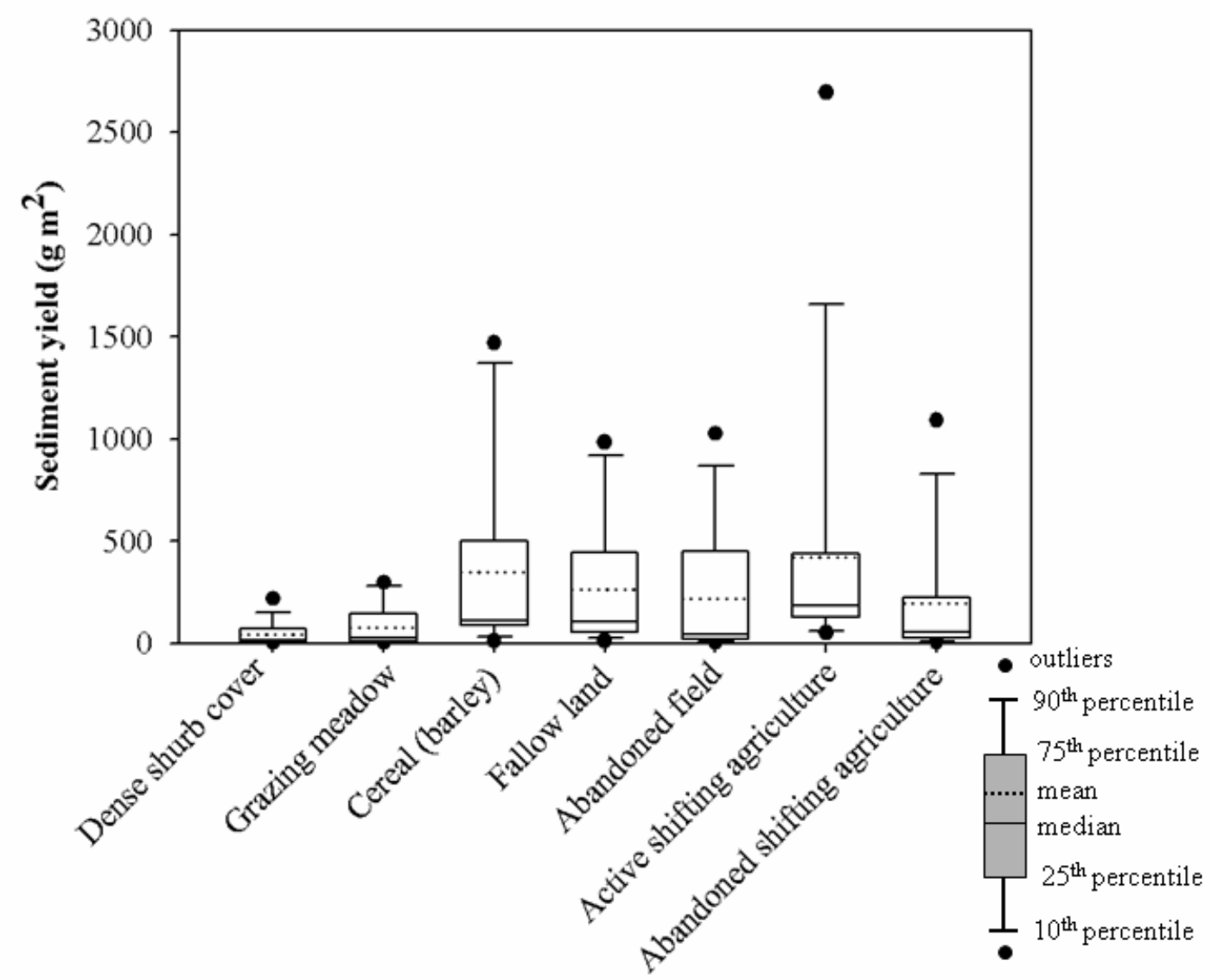


Figure 7. Trends in runoff from the various land use plots.
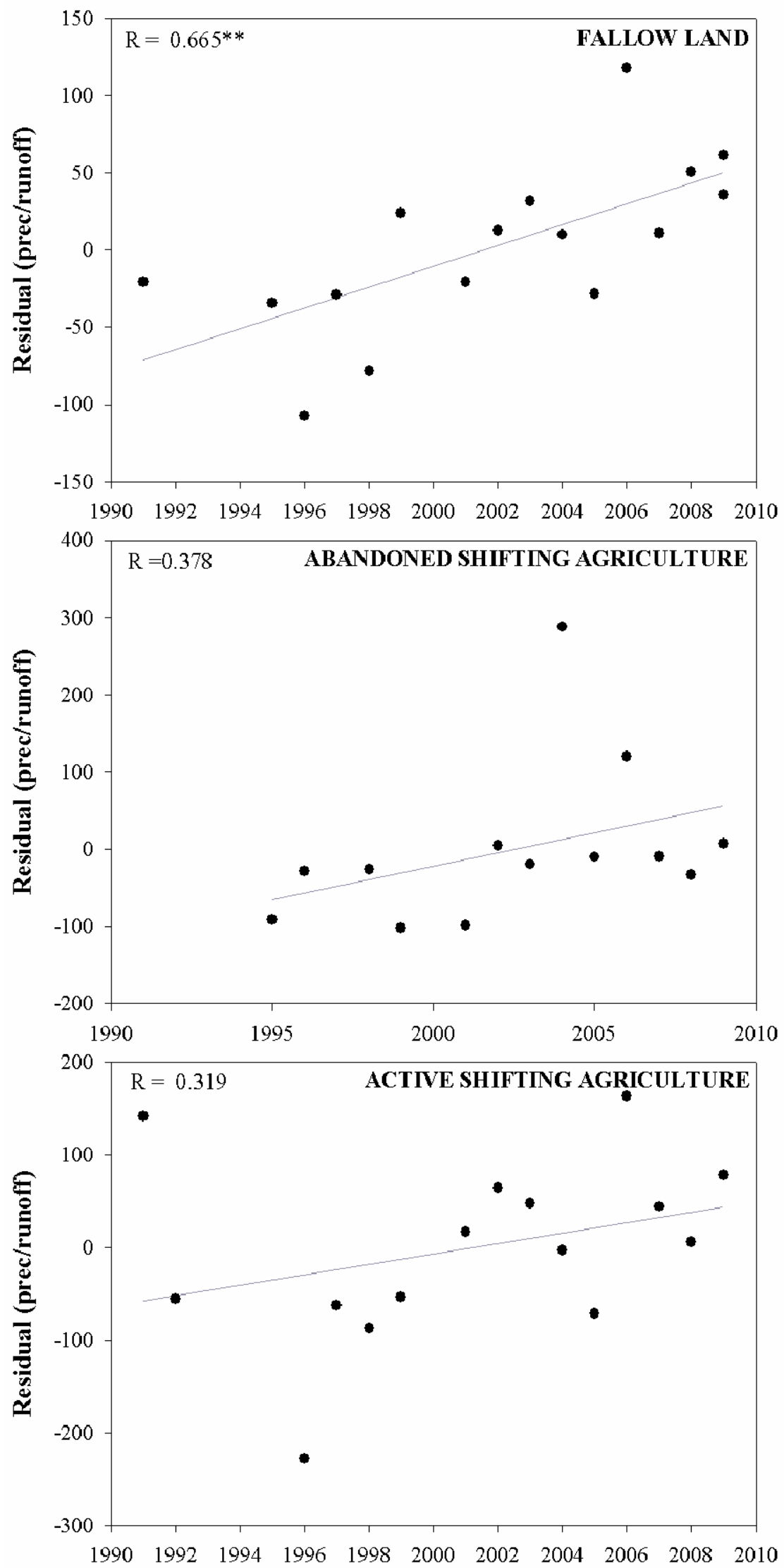
Figure 8. Trends in suspended sediment yield from various land use plots.
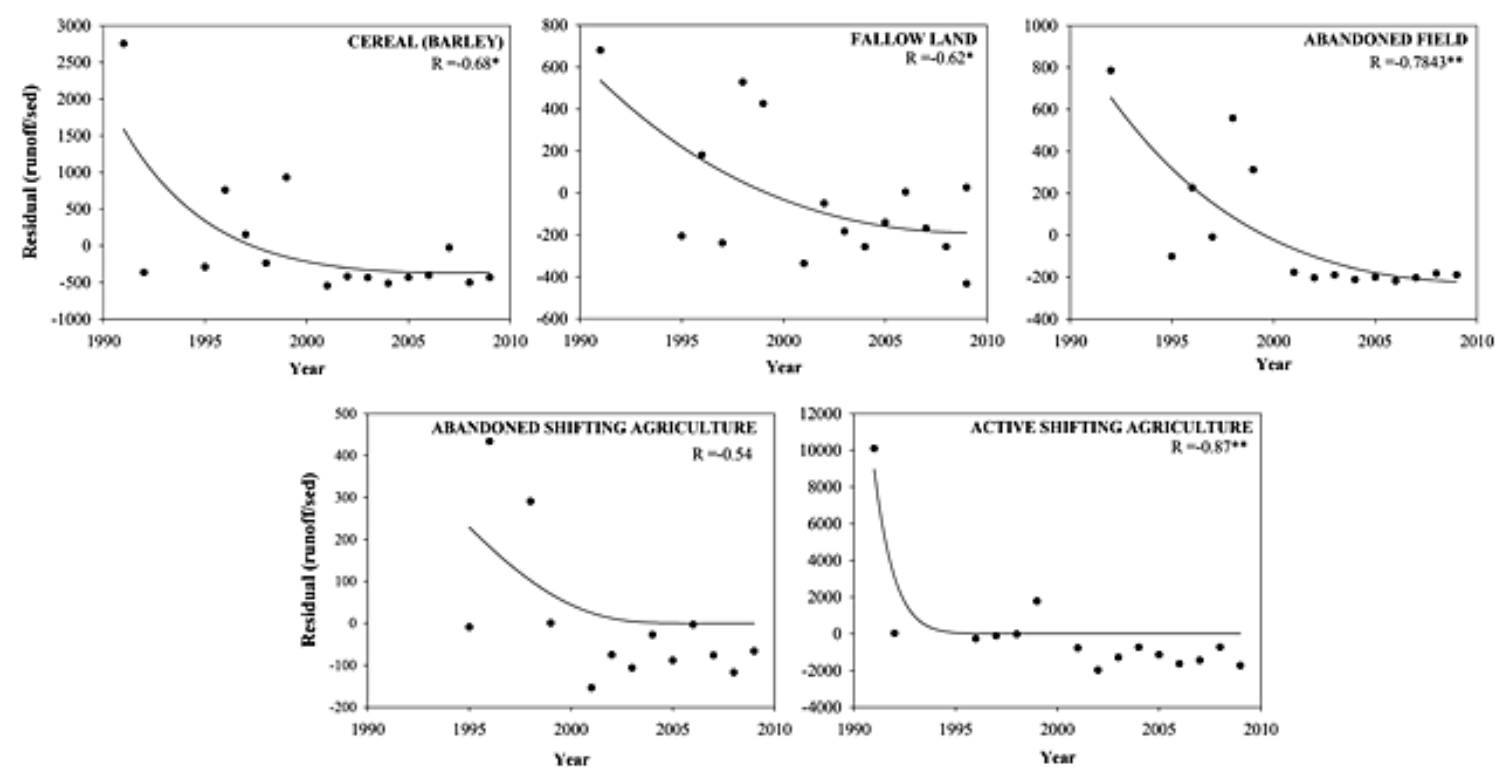

Table 1. Correlations (r) between precipitation, runoff and sediment yield

\begin{tabular}{|c|c|c|c|c|}
\hline \multicolumn{2}{|c|}{ Land use } & $\underset{f}{\text { Precipitation/runof }}$ & $\begin{array}{c}\text { Precipitation/sedimen } \\
\mathbf{t}\end{array}$ & Runoff/sediment \\
\hline \multicolumn{2}{|c|}{$\begin{array}{l}\text { Dense shrub } \\
\text { cover }\end{array}$} & $0.721 * *$ & $0.388 * *$ & $\begin{array}{c}0.665 * * \\
0.928 * * \\
\text { (exponential) }\end{array}$ \\
\hline \multirow{2}{*}{$\begin{array}{l}\text { Grazin } \\
\text { g } \\
\text { meado } \\
\text { w }\end{array}$} & $\begin{array}{c}\text { All } \\
\text { value } \\
\text { s }\end{array}$ & $0.733^{* *}$ & $0.468 * *$ & $0.557 * *$ \\
\hline & $\begin{array}{l}>10 \\
\mathrm{~g} \mathrm{~m}^{2}\end{array}$ & - & $0.580 * *$ & $0.560 * *$ \\
\hline \multirow{2}{*}{$\begin{array}{c}\text { Cereal } \\
\text { (barley) }\end{array}$} & $\begin{array}{c}\text { All } \\
\text { value } \\
\text { s }\end{array}$ & $0.731 * *$ & $0.455^{* *}$ & $0.571 * *$ \\
\hline & $\begin{array}{l}>50 \\
\mathrm{~g} \mathrm{~m}^{2}\end{array}$ & - & $0.667 * *$ & $0.875 * *$ \\
\hline \multicolumn{2}{|c|}{ Fallow land } & $\begin{array}{c}0.674 * * \\
0.730 * * \\
\text { (exponential) } \\
\end{array}$ & $\begin{array}{c}0.285^{* *} \\
0.414^{* *} \text { (exponential) }\end{array}$ & $\begin{array}{c}0.676 * * \\
0.948 * * \\
\text { (exponential) } \\
\end{array}$ \\
\hline \multicolumn{2}{|c|}{$\begin{array}{l}\text { Abandoned } \\
\text { field }\end{array}$} & $0.729 * *$ & $0.406 * *$ & $\begin{array}{c}0.536^{* *} \\
0.646^{* *}(\text { exponential } \\
\text { ) }\end{array}$ \\
\hline \multicolumn{2}{|c|}{$\begin{array}{l}\text { Abandoned } \\
\text { shifting } \\
\text { agriculture }\end{array}$} & $0.672 * *$ & $0.286 * *$ & $\begin{array}{c}0.609 * * \\
0.873^{* *} \\
\text { (exponential) }\end{array}$ \\
\hline \multicolumn{2}{|c|}{$\begin{array}{l}\text { Active shifting } \\
\text { agriculture }\end{array}$} & $0.650 * *$ & $0.268 * *$ & $0.483 * *$ \\
\hline
\end{tabular}


Table 2. Seasonal correlations between precipitation, runoff and sediment yield

\begin{tabular}{|c|c|c|c|c|c|c|c|c|}
\hline \multicolumn{3}{|l|}{ Land use } & \multicolumn{2}{|c|}{ Precipitation/runoff } & \multicolumn{2}{|c|}{ Precipitation/sediment } & \multicolumn{2}{|c|}{ Runoff/sediment } \\
\hline \multirow{2}{*}{ Dense shrub cover } & Spring & Summer & $0.678 * *$ & $0.747 * *$ & $0.480 * *$ & $0.511^{* *}$ & $0.794 * *$ & $0.472 * *$ \\
\hline & Autumn & Winter & $0.777 * *$ & $0.781^{* *}$ & $0.442^{* *}$ & $0.524 * *$ & $0.763 * *$ & $0.714^{* *}$ \\
\hline \multirow{2}{*}{ Grazing meadow } & Spring & Summer & $0.705^{* *}$ & $0.702 * *$ & $0.503^{* *}$ & $0.322 * *$ & $0.823 * *$ & $0.698 * *$ \\
\hline & Autumn & Winter & $0.816^{* *}$ & $0.713^{* *}$ & $0.429 * *$ & $0.563 * *$ & $0.549 * *$ & $0.452 * *$ \\
\hline \multirow{2}{*}{ Cereal (barley) } & Spring & Summer & $0.757 * *$ & $0.772 * *$ & $0.586^{* *}$ & $0.270 * *$ & $0.821 * *$ & $0.395 * *$ \\
\hline & Autumn & Winter & $0.779 * *$ & $0.742 * *$ & $0.448 * *$ & $0.323 * *$ & $0.359 * *$ & $0.394 * *$ \\
\hline \multirow{2}{*}{ Fallow land } & Spring & Summer & $0.646 * *$ & $0.737 * *$ & $0.370 * *$ & $0.223 * *$ & $0.693 * *$ & $0.194 *$ \\
\hline & Autumn & Winter & $0.836 * *$ & $0.722 * *$ & $0.405^{* *}$ & $0.527 * *$ & $0.426 * *$ & $0.822 * *$ \\
\hline \multirow{2}{*}{ Abandoned field } & Spring & Summer & $0.747 * *$ & $0.730 * *$ & $0.567 * *$ & $0.371^{* *}$ & $0.777 * *$ & $0.603^{*}$ \\
\hline & Autumn & Winter & $0.754 * *$ & $0.788 * *$ & $0.449 * *$ & $0.557 * *$ & $0.594 * *$ & $0.558 * *$ \\
\hline \multirow{2}{*}{ Abandoned shifting agriculture } & Spring & Summer & $0.684 * *$ & $0.713^{* *}$ & $0.394 * *$ & $0.509 * *$ & $0.767 * *$ & $0.783^{*}$ \\
\hline & Autumn & Winter & $0.670 * *$ & $0.786^{* *}$ & $0.344 * *$ & $0.520 * *$ & $0.397 * *$ & $0.786^{* *}$ \\
\hline \multirow{2}{*}{ Active shifting agriculture } & Spring & Summer & $0.662 * *$ & $0.572 * *$ & $0.361^{* *}$ & $0.371 * *$ & $0.491 * *$ & $0.447^{*}$ \\
\hline & Autumn & Winter & $0.747 * *$ & $0.702 * *$ & $0.273^{* *}$ & $0.277 * *$ & $0.550 * *$ & $0.441^{* *}$ \\
\hline
\end{tabular}


Table 3. Mean and standard deviation for runoff and sediment yield from different land uses

\begin{tabular}{|c|c|c|c|c|}
\hline \multirow{2}{*}{ 1996-2009 } & \multicolumn{2}{|c|}{ Runoff (l m²) } & \multicolumn{2}{|c|}{ Sediment yield $\left(\mathrm{g} \mathrm{m}^{-2}\right)$} \\
\hline & Mean & $\begin{array}{l}\text { Standard } \\
\text { deviation }\end{array}$ & Mean & $\begin{array}{l}\text { Standard } \\
\text { deviation }\end{array}$ \\
\hline Dense shrub cover & 64.3 & 19.6 & 41.5 & 61.9 \\
\hline Grazing meadow & 96.2 & 45.2 & 69.7 & 105.9 \\
\hline Cereal (barley) & 188.4 & 78.3 & 378.5 & 492.3 \\
\hline Fallow land & 178.4 & 94.5 & 216.0 & 274.6 \\
\hline Abandoned field & 132.6 & 54.4 & 165.1 & 248.0 \\
\hline Abandoned shifting agriculture & 162.7 & 99.7 & 199.1 & 318.7 \\
\hline Active shifting agriculture & 261.2 & 126.1 & 437.3 & 700.8 \\
\hline
\end{tabular}

